\title{
AGRICULTURE OF UKRAINE UNDER THE JOINT POLICY OF THE EUROPEAN UNION
}

\author{
Svitlana Rogach ${ }^{\text {, Larysa Vdovenko }}{ }^{2}$, Oleh Polishchuk ${ }^{3}$
}

\begin{abstract}
The purpose of this article is to study the experience of financial support of agriculture in the European Union in order to adapt it to the agricultural conditions of Ukraine. A decisive feature of European financial support to agriculture is the attitude towards it as one of the factors of development of the financial system of the European Union. Under the conditions when Ukraine tries to become a full member of the European Union, the author has proved that the modern system of financial support of agriculture in Ukraine is on the vector of formation and adaptation, therefore, the substantiation of theoretical and methodological principles and the development of practical recommendations for the improvement of existing and the introduction of progressive, recommended world practice levers and regulatory mechanisms become a determining factor in their further development. Methodology. In Ukraine, 2017 should only be expected to improve traditional forms of financial support. Among the positive points is the reduction of interest rates in UAH up to $15 \%$, but with the preservation of monetary stability, one should not expect an increase in terms of lending, in the top, there will be loans up to one year, that is, within the product cycle. Results. Ukraine is trying to take over the experience of various European countries in relation to agriculture. It relies on the experience of Germany, France, Great Britain. Practical implications. The Government and the Ministry of Agrarian Policy and Food in the Budget for 2017 presented a state support reform that creates conditions for the development of small farms and stimulates the production of value-added products, and the main principles of state support should be targeting and transparency. Value/originality. In 2017, in support of the development of the livestock sector at the expense of the general fund of the state budget under the budget program "State Support of Livestock Sector", expenditures are provided to ensure stabilization of livestock, increase its number, and stabilize production. In general, support for the agrarian sector is formal and insignificantly affecting the development of the agricultural sector, as a result of the economic and agricultural development vector declared in the 2017 Budget, in the light of economic instability, rising inflation and uncertainty.
\end{abstract}

Key words: Ukraine, EU, financial support, common agricultural policy, agriculture, demand, supply, budget, farmer, expenses, subsidy, interest rate, adaptation.

JEL Classification: F65, G21, P34, Q12

\section{Introduction}

Ukraine is a member of the European Union's Eastern Partnership program (since 2009). In 2014, Ukraine and the European Union signed the land of association, which replaced the land of partnership and cooperation between the European Communities and Ukraine.

The European Union provides the support of Ukraine to ensure a stable, prosperous, and democratic future for all its citizens. In its support, the EU is stubbornly adhering to the principle of territorial integrity and sovereignty of Ukraine and considers full implementation of the Minsk Agreements the basis of a stable political solution to the conflict in the east of the country. In the summer of 2014, the EU has increased its support for economic and political reforms in Ukraine.

The European Union is an important economic partner for Ukraine. By 2015, the European Union had 34\% of Ukrainian exports and $41 \%$ of Ukrainian imports.

The modern system of financial support of agriculture in Ukraine is on the vector of formation and adaptation

\footnotetext{
Corresponding author:

${ }^{1}$ National University of Life and Environmental Sciences of Ukraine, Ukraine.

E-mail: tuv@email.ua

ORCID: https://orcid.org/0000-0001-6940-1935

${ }^{2}$ Vinnytsia National Agrarian University, Ukraine.

E-mail: vdovenko larisa@i.ua

ORCID: https://orcid.org/0000-0002-6283-2385

${ }^{3}$ Uman National University of Horticulture, Ukraine.

E-mail: 557555@ukr.net

ORCID: https://orcid.org/0000-0002-9859-9001
} 
to the conditions of the European Union, therefore, the substantiation of theoretical and methodological principles and the development of practical recommendations for the improvement of existing and the introduction of progressive, internationally recommended levers and regulatory mechanisms become the determining factor in their further development.

The policy of financial support for agriculture in the European Union provides high results in agricultural production, economic and social processes and intensification of rural entrepreneurship.

A decisive feature of European financial support to agriculture is the attitude towards it as one of the factors of development of the financial system of the European Union.

Among all the aforesaid, useful for Ukraine should be not only the experience regarding financial support of agriculture in the European Union but also the recent changes in the Common Agricultural Policy of the European Union and the prospects for its development in the near future and hence the efficiency in solving problems.

\section{Economic crisis effects on consumer behaviour}

The purpose of the article is to study the experience of financial support of agriculture in the European Union in order to adapt it to the agricultural conditions of Ukraine.

Support for agriculture occupied about $70 \%$ of the expenditure part of the budget of the European Union in the 80 s, to $50 \%$ - in the 90 s, and continues to decline. In 2009, for example, Europe spent 57 billion euros on support for agriculture or about $41 \%$ of the EU's 140 billionth budget. In terms of the area of agricultural land in Europe, it turns out that state support was about 325 euros per 1 hectare of cultivated land. Additionally, EU countries support local producers from national budgets - about 80 euros per hectare of farmland. Thus, the total budget support in the EU countries in 2009 was 405 euros per 1 hectare of land.

The largest recipients of funds from the EU are France (about $17 \%$ of the payments accounted for by the BBC), Germany and Spain (about 13\% each), Italy (about $11 \%$ ), and Great Britain (about 7\%). On average, one farm receives about 12,200 euros of deductible per year but payments per hectare of cultivated land vary from 527 euros in Greece to 89 euros in Latvia (subsidies for new members of the European Union are much smaller). France spent 12.2 billion EUR on the agrarian sector and rural development in 2009, of which 5.7 billion EUR was from the EU budget.

Agriculture is one of the most important industrial branches of the European Union. In France, it generates 150 billion euros of commodity circulation, in the industry employs 500000 people.
France also exports agricultural products annually by 40 billion euros and the foreign trade balance for food and agricultural raw materials in the country is positive a surplus of 8 billion euros, although the foreign trade deficit of the country is about 70 billion euros.

Due to the increasing world demand for food, France wants to meet these needs. Therefore, France not only lends its producers (the total amount of loans issued by the State Agricultural Bank of France exceeded 42 billion euros) but also helps its farmers with the sale of products - for example, at the level of the Ministry of Agriculture Economy has a committee on exports to Asia which is now the highest demand for food. The Committee is engaged in the regulation of export issues, the harmonization of phytosanitary requirements, and the observance of intellectual property rights.

\section{Differences in consumer spending behaviour among age groups}

In 2011, the EU allocated 42.5 billion euros for direct payments to farmers, 3.34 billion euros for interventions and maintenance of prices for some agricultural products, and another 353 million and 254 million euros for the development of veterinary and phytosanitary control.

Therefore, there was developed a special system of financial and credit provision of agriculture, without which it could not exist. First of all, for agriculture, a preferential loan is required. So in Germany, the leading creditors and administrators of the agrarian sector of the economy are: the Union of German People's Banks and Raiffeisen Societies which includes more than 1470 credit societies uniting mainly farmers and other entrepreneurs working in the countryside; system of German savings banks; Agricultural Rental Bank in Frankfurt; German mortgage bank in Bonn; Credit Institute for Recovery in Frankfurt; private mortgage banks.

For German farmers involved in the investment incentive program or the General Agrarian Program, preferential lending is made in the form of a loan of $1 \%$ per annum or by reducing the loan interest rate on current loans by 4-7\%.

The Farm Rental Bank in Frankfurt offers farmers preferential lending under the special programs "Agriculture" and "Young Affiliates". For young farmers, loans are issued at the age of 40 years in the presence of five-year seniority.

Credits are used as a source of investment for farming, industrial infrastructure, and housing, for the purchase of a leased farm, compensation for the heirs' expenses when they become legally inherited, stimulating farmers who have deviated from agricultural activity, etc. Investments in dairy cattle breeding are funded by keeping up to 120 cows, fattening pigs - with up to 1,700 pig farms and up to 50 thousand laying hens 
for fattening poultry. Credits are not allocated for the conversion of debts, an additional purchase of means of production and low-value light-weight implements.

The Village Renewal program loans are used to preserve a typical rural landscape by preserving, repairing, and rebuilding farm buildings due to changes in the direction of their use. Individuals and legal entities, societies, and organizations, as well as groups that have joined for this purpose, have the right to receive loans under this program.

The difference in preferential lending is covered by the rental bank from current profits. One-fifth of the total volume of medium- and long-term loans from a rental bank is spent on financing loans.

Rabobank, which is the second-largest in the country, plays an important role in agriculture in the Netherlands. It is organized as a cooperative to serve the cooperative system of agribusiness of the country and provides about $90 \%$ of bank financing and lending to agricultural production. The conditions for issuing loans are established after analysing the activity of each agricultural enterprise and negotiations between the banker and the borrower.

The interest rate is very volatile and can be changed during the loan period. However, under all these conditions, the loan is in fact preferential as the bank falls under the legislation on cooperatives, which provides for preferential taxation and controlled by the union of cooperatives.

In the UK, due to the peculiarities of the economic and historical past, its credit and banking system is one of the most developed in Europe. It is characterized by a high level of division of labour between different financial institutions, broad branching, and a large variety of different types of financial and banking institutions. Through commercial banks, there are various state subsidies from the country and the EU, which makes loans in many cases preferential. Lloyd Bank, Midland Bank, Barclay Bank and others carry out the largest lending operations in agriculture. Financing of investments in agriculture is carried out mainly on the so-called permanent loan - the banker and the entrepreneur annually discuss the interest rate, the size of the loan, the type of debt, depending on the economic situation of the economy.

The central role in the system of agricultural credit in France is played by "Crédit Agricole". However, in recent decades, other financial institutions have been connected to the system of preferential lending. The mechanism of action of preferential loans in agriculture of this country is based on the principle of bonification - the state's repayment by the bank of the difference between the contractual interest rate and the preferential loan rate that was granted to the farmer. The procedure for the calculation of bonification on the basis of the contractual interest rate introduced as a result of the reform of the system of preferential credit.
In Austria, the most widespread type of preferential credit is investment agricultural loans, the rate of which is calculated based on the rate of the lender's bank; it is adjusted several times a year by the Austrian National Bank. The term of the preferential investment loan is 10 years; when purchasing means of mechanization 6 years. Thus, we can speak of the presence in developed European countries of a diverse and largely preferential system of crediting agricultural economy, calculated on real financial needs and opportunities of this industry.

A French farmer specializing in raising the Blonde d'Aquitaine breed in the Department sells them for meat at a price of 4.6 euros per $1 \mathrm{~kg}$. The heifer of the Blonde d'Aquitaine breed weighs $700-800 \mathrm{~kg}$ and eats $15 \mathrm{~kg}$ of hay per day and $1.5 \mathrm{~kg}$ of concentrated feed mixture. This year, the farmer was forced to raise the selling price by 0.30 euros per 1 kilogram (last year he sold carcasses at 4.30 euros per 1 kilogram) - gasoline, fertilizers, film for packaging of stumps and more. After deducting costs after selling meat, his profit is approximately 0,20 euros per $1 \mathrm{~kg}$. The meat is sold by a farmer to a local cooperative, which then sells it.

The farmer receives a subsidy of 225 euros per head of cattle (in the calculation of heifers) per year, and per hectare - for the cultivation of feed (he does not name them the amount), but this is not enough for life without mercy. In an economy where there is an average of 200 breeding cows, this farmer works alone and has an assistant. Employees cannot deduct them on a permanent basis only for seasonal work during the harvesting and harvesting of feed.

In the EU budget for 2012 (its total amount of 144.46 billion euros), 58.58 billion euros were put in support of agriculture and rural development including 40 billion euros on direct payments to farmers and 14 billion euros on the development of rural areas. With the European Union spending 1.6 billion euros on transport development, in support of scientific research -5.4 billion euros, on culture and education -2.69 billion euros. Compared to agriculture spending on the European Union is limited to regional development (42 billion euros in 2012) - Regional Policy, a public investment program to create new jobs, reduce the backlog of less developed regions, develop infrastructure, and attract private investment.

During 2007-2013, the European Union plans to spend about 347 billion euros on these goals, says the European Commission's website.

The European Union spending on agriculture continues to decline - already in 2013, their share in the budget has decreased to $33.1 \%$ (see Table 1), at the same time, the conditions for obtaining direct subsidies also change. Since 2013, farmers introducing new more environmentally friendly production technologies will receive additional subsidies.

For comparison, in Ukraine: in the most difficult period of the development of our economy (2007-2015), 
the GDP of the country decreased by almost $20 \%$ while agriculture showed a significant growth - about $45 \%$. In essence, the agrarian sector is the only segment of the national economy that is resistant to systemic crisis phenomena.

It would seem that the financial channel for using the accumulated in banks liquidity (70-80 billion UAH) about which search is said lately. Unfortunately, the dynamics of agricultural lending in Ukraine proves the opposite: the loan portfolio of banks in the agrarian sector is practically unchanged and amounts to $8-10 \%$ of the total that is about 50-60 billion UAH. The new lending is mainly due to the proceeds from current loans and the repayment of old debts. And this despite the fact that agrarian loans are the least problematic: part of the problem is $10-11 \%$ while the average figure on the system varies within $20-30 \%$.

At the same time, despite the substantial potential of the sector, there is no systematic growth of lending as was the case for example in the middle of the 2000s.

European farmers also have privileges for loans. For the purchase of new agricultural machinery, they can raise funds at 3-4\% per annum, for the purchase of land - at around $7 \%$ per annum. It has several thousand ducks on the family farm which are fed to foie gras. In France, subsidies are received for the cultivation of land, for the cultivation of feed, but specifically for the bird - no. Foie gras in the local market costs about 30 euros per $1 \mathrm{~kg}$ (the liver of one duck weighs 400-500 g), duck meat - about 3 euros per $1 \mathrm{~kg}$. Processing greatly raises the selling price - canned foie gras is already 60-90 euros per $1 \mathrm{~kg}$.

The number of private farms, family farms in Europe is steadily declining - the profitability of small farms is still lower than that of large industrial enterprises and here the state support does not help.

The fight for high-quality agricultural products in the European Union leads to the fact that the industry has become much overregulated. The farmer must receive a large number of certifications and constantly confirm the compliance with veterinary requirements at all stages of production. The reason is that few farmers sell their products to end users. The product goes through a long chain, in which no link want to assume full responsibility for quality. This leads to such tightening of regulation in the first stage.

Competition is strong inside the European Union. France with its high taxes and a relatively high minimum wage (about 2000 euros without taxation) is not in the same conditions with Portugal or Greece where social taxes are lower and hired workers are much cheaper. Therefore, French farmers are trying to compete not so much in the price field as in quality.

Therefore, the EU countries are trying to specialize in those segments that can be most effective.

\section{Survey methodology}

The Government and the Ministry of Agrarian Policy and Food in the Budget for 2017 presented a state support reform that creates conditions for the development of small farms and stimulates the production of valueadded products and the main principles of state support should be targeting and transparency.

In this connection, three strategic directions are envisaged: state support for farmers, rural development and completion of land reform and the five priorities that follow from them. This is the development of markets, organic production, irrigation, and food safety.

The corresponding order was approved by the Cabinet where the government compensates for potential losses of domestic farmers from the abolition of special VAT regime from January 1, 2017.

The Budget for 2017 identified three sources of support for the Ukrainian agrarian sector: budget funds for general and special funds, European Development Bank loan funds, state guarantees.

The share of the agrarian budget in the state budget expenditures is set at $0.96 \%$ indicating a levelling of the downward trend in 2015-2016 when it did not exceed $0.37 \%$. However, compared to the 2013 structure, it is only $1 / 2$.

Financial support to the agro-sector is a key component of Ukraine's agrarian policy. In practice, having inherited a planned economy in which agriculture was subsidized at the level of $70 \%$, the government is constantly concerned about the formation of the financial balance of the industry traditionally continuing and modifying

Table 1

Budget development programs - expenditures of agricultural commodity producers for 2013-2017, million UAH

\begin{tabular}{|l|c|c|c|c|c|c|c|c|}
\hline \multicolumn{1}{|c|}{ Budget classification programs } & $\begin{array}{c}2013 \\
\text { fact }\end{array}$ & $\begin{array}{c}2014 \\
\text { fact }\end{array}$ & $\begin{array}{c}2015 \\
\text { fact }\end{array}$ & $\begin{array}{c}2016 \\
\text { fact }\end{array}$ & $\begin{array}{c}2017 \\
\text { fact }\end{array}$ & $\begin{array}{c}\text { Reduction } \\
\text { in 2017 vs. } \\
2013,+/-\end{array}$ & $\begin{array}{c}\text { Reduction } \\
\text { in 2017 vs. } \\
2016, \%\end{array}$ & $\begin{array}{c}\text { Reduction } \\
\text { in 2017 vs. } \\
2013, \%\end{array}$ \\
\hline $\begin{array}{l}\text { Financial support of measures } \\
\text { by cheapening of loans }\end{array}$ & 0,96 & - & 290,64 & 300 & 300 & - & 100 & 31250 \\
\hline Financial support of agribusiness activities & - & - & - & 5 & 60 & 55 & 1200 & - \\
\hline Support for gardening & 94,79 & 371,2 & 40,58 & 50 & 210 & 160 & 420 & 29,2 \\
\hline Financial support of commodity producers & - & - & - & - & 2973 & 2973 & - & - \\
\hline Total & 816,75 & 415,13 & 331,23 & 355 & 3618 & 3263 & 1019,2 & 443 \\
\hline
\end{tabular}

Source: formed according to Zakon Ukrainy 


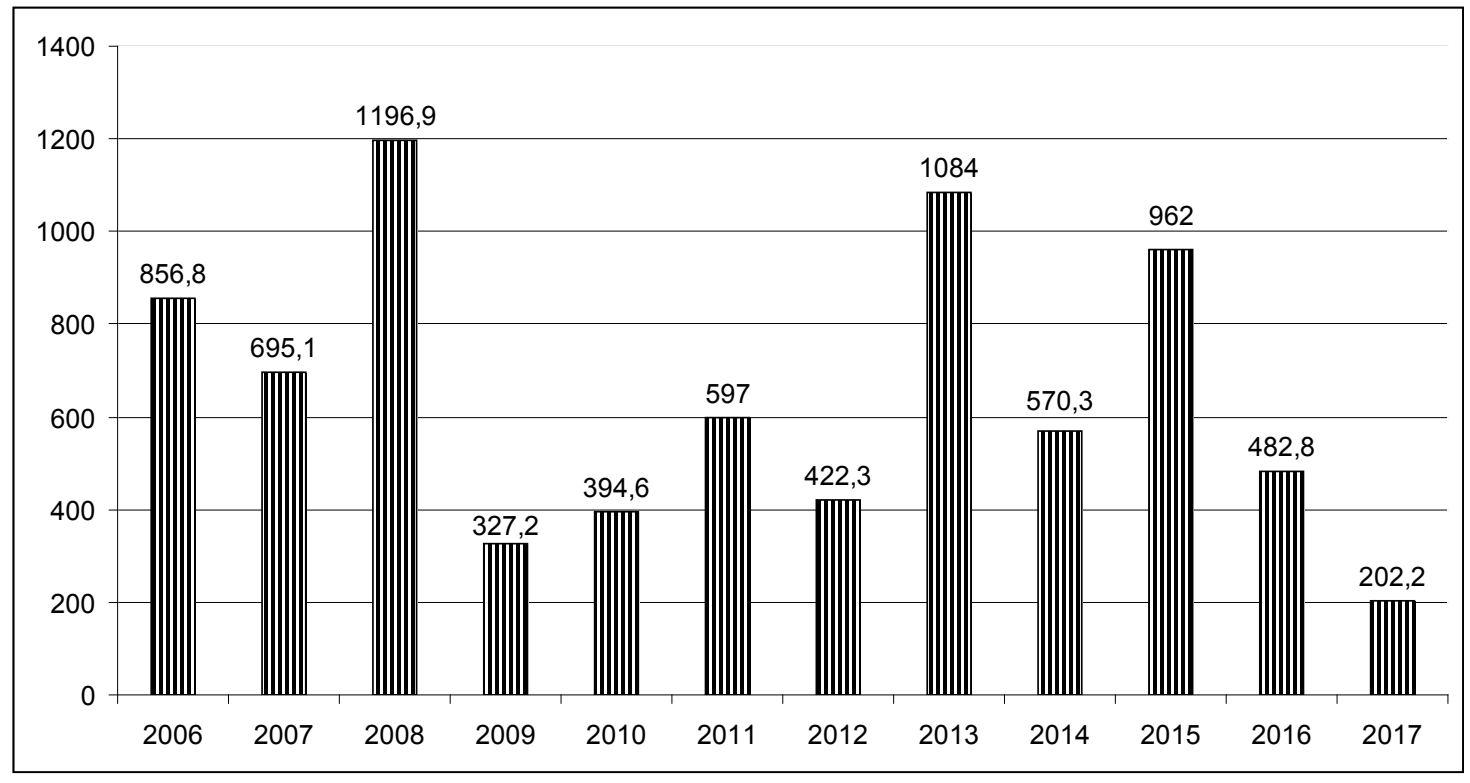

* - data for 2017 are given in the half-year

Figure 1. Credit resources of agricultural enterprises of the Vinnytsia region, billion UAH

Source: According to the data of the Vinnytsia Regional State Administration

the practice of state support. The basic directions of support are defined - assistance to small business, the formation of stable economic forms, development of organic production, stimulation of value-added chains at all stages of their formation, solving of socio-economic problems of rural areas' development.

In the system of state support, preferential credit occupies a special place. For agricultural enterprises, partial compensation for interest rates on bank loans was introduced in 2000, given the critical state of nonrepayment of loans over the stagnation of production. Initially, lending programs were intended to finance production costs. In the future, preferential credit extends to resources, in particular, from 2004 according to the Resolution of the Cabinet of Ministers of Ukraine No. 184 as of February 18, 2004, through the mechanism of cheapening short-term and long-term loans.

The general tendency of lending to the agrarian sector is confirmed by the industry, for example in the Vinnytsia region is shown in Figure 1. That is, the state of lending depends on the state of smoothing the conflict of interests of producers, banks, and the volume of the state budget.

Analysing the indicator of the financial leverage, we observe the proportion of credit claims in the assets of agribusinesses.

\section{Findings}

In terms of agricultural development expenditures the Budget 2017 is unprecedented compared with the relatively well-off for 2013 it is planned to 4.4 times more and compared to the actual implementation in 2015 - more than 11 times.
In support of the development of agricultural enterprises, 3.761 billion $\mathrm{UAH}$ were foreseen in the following areas: financial support of agricultural producers (new program, per 1 hectare area) - 2.973 million UAH (78\%); cheaper loans - 300 million UAH (8\%); livestock support - 210 million UAH (6\%); support for the laying of and maintenance of young gardens, vineyards, and berries - 75 million UAH (2\%); support for activities in the agro-industrial complex - 60 million UAH (2\%) (support of service cooperatives, creation of a reserve stock of seeds, cheapening of insurance premiums).

The program of cheapening loans is regulated by the Resolution of the Cabinet of Ministers of Ukraine dated April 29, 2015, No. 300 "Procedure for using the funds provided for in the state budget for financial support of measures in the agro-industrial complex by reducing the cost of loans" which states that compensations are subject to interest rates on loans borrowed to cover costs associated with the purchase of fuels and lubricants, seeds, fertilizers, plant protection products, feed, raw materials and ingredients for the production of mixed fodders, energy carriers and payment for services related to repairs agricultural and irrigation machinery, works (services) for the preparation and cultivation of soil, sowing, plant protection against diseases and pests, topdressing and signup, harvesting (Furtwengler, 2012).

In 2017, in support of the development of the livestock sector at the expense of the general fund of the state budget, under the budget program titled "State Support for Livestock Sector" expenditures amounting to 0.210 million UAH are foreseen to stabilize livestock, increase its number, and stabilize production. 


\section{Conclusions}

Unfortunately, in Ukraine in 2017, only the improvement of traditional forms of financial support should be expected. Among the positive points is the reduction of interest rates in UAH to $15 \%$ but with the preservation of monetary stability. Don't expect an increase in lending terms. There will be loans up to one year that is within the product cycle. The base currency is $\mathrm{UAH}$, foreign currency loans will be gradually replaced by the market. The prevailing forms of lending will be short-term credit lines and seasonal financing.

Budget for 2017 is the successor to more programs that operated in 2013-2016 while developing new directions, primarily small business support. It can be stated that it managed to combine the needs of the majority of agricultural producers. However, in general, support for the agrarian sector is formal and insignificantly affecting the development of the agricultural sector, as a result of the economic and agricultural development vector declared in the 2017 Budget, in the light of economic instability, rising inflation, and uncertainty.

As small commodity producers form rural employment and internal food security and a variety of agricultural products, primarily organic, as well as the requirements of international partners of Ukraine and in line with the practice of the Common Agricultural Policy of the European Union, which Ukraine seeks to join, such a vector of state support for agriculture for a time is justified.

\section{References:}

Zakon Ukrainy "Pro Derzhavnij byudzhet Ukrainy na 2016 rik". Retrieved from: http:/ /zakon3.rada.gov.ua/laws/ show/928-19

Zakon Ukrainy "Pro Derzhavnij byudzhet Ukrainy na 2017 rik". Retrieved from: http:/ /zakon5.rada.gov.ua/laws/ show/1801-19

Yedina kompleksna strategiya ta plan dij rozvitku silskogo gospodarstva ta silskih teritorij v Ukraini na 2015-2020 roki. Retrieved from: http://minagro.gov.ua

Aleskerova, Yu. V. (2009). Kredituvannya regionalnogo APK. Zbirnik naukovih prac. 17(2), 645-648.

Aleskerova, Yu., Mulyk, T., Fedoryshyna, L. (2018). Improving credit protection analysis methods Reports of main agricultural enterprises. Baltic Journal of Economic Studies, 4(2), 1-7. doi: 10.30525/2256-0742/2018-4-2-1-7

Aleskerova, Yu., Fedoryshyna, L. (2018). Analysis of investment activities of enterprises of Ukraine. Economic system development trends: the experience of countries of Eastern Europe and prospects of Ukraine.

Aleskerova, Yu. V. (2008). Analiz stanu ta efektivnosti kreditnogo zabezpechennya vidtvorennya osnovnikh zasobiv silskogospodarskikh pidpriemstv [Analysis of the status and effectiveness of credit support for reproduction of fixed assets of agricultural enterprises]. Oblik i finansi APK, 3, 125-129.

Furtwengler, D. (2012). Pricing for profit: how to command higher prices for your products and sendees, New York: American Management Association.

Pannozzo, A. (2007). The (ir)relevance of technology: creating a culture of opportunity by design. Design Management Institute Review, 18, 18-24. 